\title{
The Bucharest Stock Exchange: A Starting Point in Structuring a Valuable CSR Index
}

\author{
Mirela Clementina Panait ${ }^{1,2, *(\mathbb{D}}$, Marian Catalin Voica ${ }^{1, * \mathbb{C}}$, Eglantina Hysa ${ }^{3}{ }^{\mathbb{C}}$, Alfonso Siano ${ }^{4}$ \\ and Maria Palazzo ${ }^{4}$
}

check for

Citation: Panait, Mirela Clementina, Marian Catalin Voica, Eglantina Hysa, Alfonso Siano, and Maria Palazzo. 2022. The Bucharest Stock Exchange: A Starting Point in Structuring a Valuable CSR Index. Journal of Risk and Financial Management 15: 94. https://doi.org/10.3390/ jrfm15020094

Academic Editor: Eleftherios I. Thalassinos

Received: 27 January 2022

Accepted: 16 February 2022

Published: 21 February 2022

Publisher's Note: MDPI stays neutral with regard to jurisdictional claims in published maps and institutional affiliations.

Copyright: (C) 2022 by the authors. Licensee MDPI, Basel, Switzerland. This article is an open access article distributed under the terms and conditions of the Creative Commons Attribution (CC BY) license (https:// creativecommons.org/licenses/by/ $4.0 /)$.
1 Department of Cybernetics, Economic Informatics, Finance and Accounting, Petroleum-Gas University of Ploiesti, 100680 Ploiesti, Romania

2 Institute of National Economy, Romanian Academy, 010374 Bucharest, Romania

3 Department of Economics, Epoka University, 1032 Tirana, Albania; ehysa@epoka.edu.al

4 Department of Political and Communication Sciences, University of Salerno, 84084 Fisciano, Italy; mpalazzo@unisa.it (M.P.); sianoalf@unisa.it (A.S.)

* Correspondence: mirela.matei@upg-ploiesti.ro (M.C.P.); catalin.voica@upg-ploiesti.ro (M.C.V.)

\begin{abstract}
The aim of this article was to identify the role and specific mechanisms of the stock exchange in promoting corporate social responsibility (CSR) and CSR communications among companies listed on the Romanian capital market given country membership of the European Union. Taking into account the quality of the Bucharest Stock Exchange (BSE) as a member of the Sustainable Stock Exchanges, as well as BSE's concerns about promoting CSR, a CSR index was built to capture the specific actions of companies listed on this market. The public companies were considered representative for the promotion of CSR based on their size and other relevant features. The index can be seen by companies that can further develop it, test its validity, and employ it as a tool to reassure investors who will decide to spend their money to buy shares and stocks of organizations ranked in the BSE.
\end{abstract}

Keywords: CSR; CSR communications; CSR index; Bucharest Stock Exchange (BSE); investors

\section{Introduction}

The need to promote sustainable development has generated changes in behavior, not only in companies but in financial market institutions that, through various means, try to turn challenges into business opportunities for issuers and portfolio investors (Adam and Shavit 2008; Manea et al. 2020). For instance, exchange rate stability is found to be the main source for fostering sustainable economic growth that monetary authorities and national governments should pay attention to in adopting an exchange rate policy that leads to stable exchange rates (Morina et al. 2020). Furthermore, as suggested from other studies (Corsini et al. 2021; Vesci et al. 2021) following COVID-19, the frugal economy can be considered an important strategy in response to crises, aiming to maximize the efficient utilization of resources and finances in a country from the perspective of all stakeholders in the economy (Manta et al. 2021). International organizations such as the United Nations, the World Bank, or the OECD become involved to facilitate the transition to the green economy by promoting the principles of sustainable development at multiple levels, given the complexity of this process and the need for resources to finance this process (Raimi et al. 2015; Khan et al. 2021). The main initiatives at the international level that impact the promotion of sustainable development principles by companies are the Universal Declaration of Human Rights, the OECD Guidelines for Multinational Enterprises, the ILO's Declaration on Fundamental Principles and Rights at Work, the UN's Convention Against Corruption, and the Rio Declaration on Environment and Development (EU Parliament's 2020). 
The launch of the Global Compact principles for companies by the United Nations was a modest step towards making firms aware of their major role in the transition to the green economy and their duty to strive to internalize negative externalities through various means (Dobrowolski and Sułkowski 2020; Sułkowski and Dobrowolski 2021). One such method consists of CSR programs, through which environmental and social parameters are followed to assess the impact of the activity of corporate entities (Peršić et al. 2017; Venturelli et al. 2017). Subsequently, these principles were adapted for other entities, such as portfolio investors or universities. The launches of the Principles for Responsible Investment (PRI) in 2006 and the Principles for Responsible Management Education (PRME) in 2007 were steps made by different stakeholders in the complex process of achieving sustainable development goals (Zaman et al. 2012; Naseem et al. 2019). In addition, institutions of capital markets have generated a new approach, namely, the Sustainable Stock Exchanges (SSEs) initiative launched in 2009. This initiative is intended to be a platform not only for dialogue and exchange of good practices among stock exchanges, financial supervisors, issuers, and portfolio investors but for financing the business opportunities presented by Sustainable Development Goals (SDGs). Achieving these bold goals will not only involve multiple categories of stakeholders but novel financing solutions, given that, at least in some cases, the transition to the low-carbon economy supposes high costs that call into question the competitive pressures faced by companies (Panait et al. 2021). The public authorities must facilitate the involvement of companies in this process by supporting the corporate sector in this bold step by creating the legal, institutional, and financial framework in which this step will be taken (Zaman and Goschin 2010; Brezoi 2018; Drăgoi et al. 2018; Apostu et al. 2019; Frone et al. 2020; Vasile et al. 2021).

Another important legislative aspect that regulates CSR activities in Europe and, subsequently, in Romania is the Directive 2014/95/EU (nonfinancial reporting directive (NFRD)). The NFRD applies to large companies with more than 500 employees. This includes large, listed companies; however, the latest talks concluded that the scope of the NFRD should be expanded. Furthermore, there is strong support for standardizing some rules and principles within the NFRD (EU Parliament's 2020).

The reshaping of companies' behavior occurs through a natural process of coercive, mimetic, and normative isomorphism (DiMaggio and Powell 1983; Beckert 2010; AmorEsteban et al. 2018, 2020). More and more scientific studies have analyzed the applicability of these concepts and of the institutional theory in the field of CSR. Companies are in a continuous process of adaptation and capitalization on the opportunities offered by the need to promote sustainable development on different levels (Gurtu 2020). Thus, companies initiate and carry out various CSR actions under pressure from different categories of stakeholders, mainly clients and portfolio investors, but also to keep up with the trend, given that competing companies or those with which they are in various collaborative relationships have socially responsible behavior (Gigauri 2021). The involvement of universities in the process of promoting the principles of sustainable development and the Global Compact principles for responsible management has also generated a normative isomorphism over time through the contributions of professional associations and employees (Masud et al. 2019; Hysa 2014; Hysa and Mansi 2020). Universities are becoming more aware of their role in society and the contributions they might make to promoting CSR (Lee and Kim 2017; Andrei et al. 2018). In addition, legal regulations regarding the obligation to publish nonfinancial information for certain categories of companies, such as those listed on the stock exchange, generated a certain standardization regarding the published data, as well as a certain mimicry from smaller companies that wanted to send a positive signal to stakeholders regarding their involvement in promoting sustainable development (Najm-Ul-Sehar and Tufail 2013; Tiron-Tudor and Nistor 2019; Khan et al. 2019; Yang et al. 2019; Yu et al. 2020). 
The aim of this article was to identify the role and specific mechanisms of the stock exchange in promoting CSR among companies listed on the Romanian capital market given Romania's membership in the European Union, which, at least declaratively, is a pole of CSR worldwide. The EU's concerns about promoting the principles of sustainable development and CSR are also felt in the real economy. More and more large companies support the sustainable development process and, whether voluntarily or obliged by legal regulations, annually publish increasingly complex information on social and environmental performance.

The present article is structured into several parts. After the introduction, analysis is presented of the position of the Bucharest Stock Exchange as a regional player. In the next section, the main CSR and sustainability indices are presented as a starting point for the construction of a CSR index on the Romanian capital market. The technical details regarding the creation of this index are presented in the section data and methodology. In the conclusions section, the authors present their interpretation of the obtained results, the limits of this research, and future research directions.

\section{Background}

\subsection{The Bucharest Stock Exchange (BSE) as Regional Player}

The fall of communism generated numerous changes both conceptually and institutionally in the countries of Central and Eastern Europe. In Romania, the first germs of the capital market appeared by adoption of company laws (1990), which set up general conditions for establishment of joint stock companies and issue of securities, i.e., shares and bonds. Although the first financial securities were available, and the privatization law spoke about the institution of the stock exchange, the first law regulating the stock exchange activity was adopted only in 1994. The Romanian government drafted the law within the 6-month deadline set by the privatization law, but the law was adopted by Parliament very late Compared to other countries in the region, capital market institutions were established late in Romania (Matei et al. 2008), and the gap with other Central and Eastern European countries has not only been maintained, but even deepened (Barna and Mura 2010), both quantitatively and qualitatively. Furthermore, the supply of listed financial products is modest and even decreased considerably after the completion of the merger process between the two Romanian stock exchanges (BSE and Sibiu Stock Exchange-SIBEX) in 2018.

The Bucharest Stock Exchange - the standard of the Romanian capital market, was established hardly in 1995, as an institution of public interest. Initially, BSE was organized as a stock market; it does not play the specific role of the market economy (Barna and Mura 2010), namely, to offer an alternative financing for agents, being almost exclusively a market for speculative operations (Cozorici and Prelipcean 2015). Poor financing of economic agents based on capital market specific mechanisms can be explained by the strength of the Romanian banking system that ensures financial funds for local companies; precarious financial education specific to stock markets in former communist countries; the lack of trust in capital market institutions given the numerous scandals, such as the case of National Fund of Investment (a pyramidal scheme presented as an investment fund); or thefts of shares undertaken even by brokers (Matei 2013; Ene and Panait 2017). The preponderance of speculative operations on the Romanian market is also supported by the rapid desire to enrich local investors, who do not expect long-term gains, but want immediate profits, without often making a fundamental valuation of assets held or who want to trade them (Dragota et al. 2009). Domestic investors even show a low-risk aversion, and investment behavior is influenced by factors such as sex, social status, education, or occupation. Moreover, there is a decrease in risk aversion as market efficiency and investor income increase, and experience of capital market players improves; in this way, new investment opportunities appear. 
The appetite for risk can be explained in some cases by the lack of financial education, as the communist period left significant traces on the financial behavior of the population (Dragotã 2006; Ene and Panait 2017). However, studies conducted for Romanian market have demonstrated the importance of speculative operations for generating economic growth (Brasoveanu et al. 2008). Furthermore, 1995 was a modest year, as only five stock exchange meetings took place, which can be explained by the fact that only some listed companies started trading in November (initially, nine joint stock companies were listed, but the number of companies increased remarkably, reaching 127 in 1999, and later stabilized around 80 companies) and the low level of financial education, especially among the population. In fact, in Romania, the capital market began to become known among the population only after the launch of the RASDAQ market, by listing over 5000 companies that were subject to the process of mass privatization. By launching the mass privatization program, Romanian citizens received coupons that had to be subscribed to the companies included in this program and the shares could be traded on this market created as a complementary segment of BSE. Initially, on RASDAQ, there were significant trading volumes in this market in terms of value as a result of trading the coupons received by the population through the mass privatization program. Through this market, there was an administrative privatization of companies with state capital and not one initiated and desired by the management of these companies. In 2002, this market was reorganized and transformed into a joint stock company-RASDAQ Electronic Exchange (BER). Gradually, the number of listed companies decreased considerably from about 5000 in 1996 to about 1200 in 2007 as a result of delisting generated by shareholder decisions and the need to comply with the requirements for maintaining this market (Anghelache 2007).

In the following years, important events take place that offered some consistency to the stock market activity, namely the admission to the stock exchange of some companies of national importance (Terapia Cluj Napoca, Antibiotice Iasi, Alro Slatina, Policolor and Automobile Dacia in 1997 and Petrom and Romanian Bank of Development in 2001) and the listing of the five financial investment companies in 1999. In addition, we are witnessing an increase in the stability of the stock market activity by the withdrawal of many companies from official segment (in 2001), because they did not meet the new listing conditions imposed by BSE in 2000 or they were delisted as a result of the change in the shareholding structure, (the companies were takeover by foreign investors). Delisting from the stock exchange is a common phenomenon, specific to developed markets that have experienced numerous withdrawals from the stock exchange over time, which led to subsequently listing on the regulated capital market of large companies. The delisting of a large number of issuing companies (50), as well as scandals (theft of shares) involving brokers, led to a substantial reduction in the number of intermediaries from 110 to 75 in 2002. In 2021,only 26 brokerage companies operated on the market.

In Romania, there is a tendency to consolidate the stock market by initiating mergers and acquisitions between different institutions. Thus, the absorption of the Romanian Association of Securities Dealers Automated Quotation (RASDAQ) market by BSE takes place in 2005. This market was created in 1996, as an alternative to BSE for companies that entered the process of mass privatization, listed as small and medium-sized companies that did not meet BSE standards (Anghelache 2007). To achieve the merger by absorption between BSE and BER, we are also witnessing in advance the transformation of BSE into a joint stock company. Thus, the demutualization process is also manifested in Romania, which marks a step towards Romania's integration into the EU (Anghelache 2007). In 2014, the Romanian Parliament adopted a normative act (law 151/2014) abolishing the RASDAQ market (Anghelache and Panait 2016). This is due to the requests of the European Commission regarding the clarification of the legal status of the shares traded on the RASDAQ market and the need to align with the provisions of the European directives with incidence in the field the capital market. Through this normative act, the situation of the shares traded on the RASDAQ Market was clarified. The companies listed on RASDAQ had to decide to list on a regulated market or in an alternative trading system. 
In 2018, BSE merged with the Sibiu Stock Exchange (SIBEX), which was established as a joint stock company based on a private initiative since 1994. SIBEX stood out in the Romanian landscape through derivative transactions (futures and options) whose assets were supported either the shares of companies listed on the BSE or certain fungible goods such as gold and silver. The mechanisms of Bucharest Stock Exchange were used to a small extent for the privatization of state owned companies. The reduced use of capital marketspecific methods is due to inadequate legal regulations, the need to select the brokerage company to mediate on the market, and low prices obtained due to the short payment term and market conditions.

Compared to other stock exchanges in the region, the Bucharest Stock Exchange has a modest position, from the point of view of transactions with shares and bonds, but also from the point of view of traded instruments (Tables 1 and 2). The motivations are multiple and consist in the late establishment of the stock market in Romania compared to the competing markets in Central and Eastern Europe, as well as the reduced use of capital market mechanisms for the privatization of state-owned companies or for the financing of local companies.

Table 1. Domestic equity trading.

\begin{tabular}{cccc}
\hline & & & \multicolumn{2}{c}{ Electronic Order Book } \\
\cline { 3 - 4 } Exchange & Trading Days & Trades & Turnover (EUR m) \\
\cline { 3 - 4 } \%o Turnover Velocity & 120.0 \\
Bucharest Stock Exchange & 249 & 694,459 & 2110.0 \\
Budapest Stock Exchange & 251 & $2,103,902$ & 9468.5 \\
Bulgarian Stock Exchange & 247 & 58,836 & 174.0 \\
Nasdaq Nordics \& Baltics & 255 & $219,648,896$ & $858,814.5$ \\
Prague Stock Exchange & 250 & 682,069 & 3420.1 \\
Warsaw Stock Exchange & 252 & $38,149,076$ & $69,472.9$ \\
Zagreb Stock Exchange & 250 & 121,682 & 305.8 \\
TOTAL FSE & & $950,515,123$ & 200.0 \\
\hline
\end{tabular}

Source: The Federation of European Securities Exchanges (FESE).

Table 2. Total bond and money market instruments trading.

\begin{tabular}{cccc}
\hline \multirow{2}{*}{ Exchange } & Trading Days & \multicolumn{2}{c}{ Electronic Order Book } \\
\cline { 3 - 4 } & & Trades & Turnover (EUR m) \\
\hline Bucharest Stock Exchange & 249 & 694,459 & 2110.0 \\
Budapest Stock Exchange & 251 & $2,103,902$ & 9468.5 \\
Bulgarian Stock Exchange & 247 & 58,836 & 174.0 \\
Nasdaq Nordics \& Baltics & 255 & $219,648,896$ & $858,814.5$ \\
Prague Stock Exchange & 250 & 682,069 & 3420.1 \\
Warsaw Stock Exchange & 252 & $38,149,076$ & $69,472.9$ \\
Zagreb Stock Exchange & 250 & 121,682 & 305.8 \\
TOTAL FSE & & $950,515,123$ & $6,166,583.6$ \\
\hline
\end{tabular}

Source: The Federation of European Securities Exchanges (FESE).

\subsection{CSR and Sustainability Indices}

The explosion of stock market indices helps to explain the intensification of the financial innovation process (Sun et al. 2011; Skouloudis et al. 2016). Originally created as stock indices to calcluate the performance of blue-chip companies in the US market, the stock market index has seen a spectacular evolution, both in terms of calculation methodology and in terms of the basket of assets underlying the index (Mynhardt et al. 2017). The technical progress allowed the creation and use of complex calculation formulas, such as the arithmetic mean and the geometric mean (Najm-Ul-Sehar and Tufail 2013; Nakai et al. 2013). The interest in stock indices is also demonstrated by the fact that more and more entities are involved in launching and calculating stock indices (Matei et al. 2008; Yu et al. 
2020). We note the economic publications, such as the Financial Times, the rating agencies (Standard and Poor's), but also many brokerage firms launch indices.

The need to promote sustainable development by different categories of economic agents has generated a paradigm shift regarding the involvement of companies in the economy and rethinking management strategies, but also the dissemination of information to different categories of stakeholders (Palazzo 2019; Palazzo et al. 2020a). The complexity of the sustainable development phenomenon has not only generated constraints for companies, but also the launch of national, regional, and international initiatives by various institutions through which companies are offered tools and mechanisms for efficient action in the process of transition to low carbon economy (Palazzo et al. 2019, 2020b). The increase of pressures from internal and external stakeholders has helped to shape increasingly responsible corporate behavior of companies. Nowadays, the firms are interested in maximizing profits for shareholders, as well as improve the social and environmental impact of their activities (Siano et al. 2020).

In order to generate reactions corresponding to the efforts made, the dissemination of financial and non-financial results becomes increasingly important, the companies creating sustainability or CSR sections on their own sites, or elaborating annual CSR or sustainability reports (Vollero et al. 2018). As a natural reaction, "to help highlight corporations with exemplary sustainability performance, a number of ratings, awards, and indices have emerged" (Searcy and Elkhawas 2012).

In this way, capital market investors have the opportunity to track the financial performance of shares issued by companies with sustainable behavior. Gradually, the interest of investors has really increased and, nowadays, the concept of socially responsible investments is well known, both on the financial market (Gjølberg 2009; Batista and Carlos de Francisco 2018; Wu et al. 2018; Panait et al. 2021; Ur Rehman et al. 2021) and in academic plans. The universe of socially responsible investments is constantly expanding. An important contribution to this process is made by United Nation, which launched six Principles for Responsible Investment (PRI) in 2006. In 2021, the PRI's network includes over 3700 signatories, $90 \%$ of them which are based in developed markets.

The stock exchanges come in support of portfolio investors and have launched sustainability or CSR indices (Lemke and Bastini 2020; Khan et al. 2021). The selection criteria of companies for these indices are based on the responsible behavior of issuers, as a rule, from the first category of the stock exchange, excluding companies from sectors, such as tobacco production or weapons (Daszyńska-Żygadło 2019). These indices are important for the business world because they capture the economic, environmental, and social performances of companies in different fields of activity (Arribas et al. 2019; Panait et al. 2021), including:

- The Dow Jones Sustainability Index (DJSI) Series;

- The Calvert Social Index;

- The FTSE4Good Series;

- The KLD Global Sustainability Index Series.

Despite the rigorous criteria set by stock exchanges or rating agencies that launch such indices, the media draws attention to the frequent violations of ethical or socially responsible behavior by companies in the index basket. The study of Arribas et al. 2019 for the Dow Jones Sustainability Index used information available in the Eikon Thomson Reuters database, regarding negative news or controversies. The results of the analysis showed a decrease in the number of selected companies that were involved in controversial actions covering seven categories, namely environment, products, management team and shareholders, community, labor, and human rights. This demonstrates increased attention from entities that launch such indices to exclude companies with chameleon behavior that claim responsibility but, in reality, have irresponsible behavior. 


\section{Data and Methodology}

Given the quality of BSE as a member of Sustainable Stock Exchanges as well as BSE's concerns for promoting CSR, the article aims to build a CSR index that captures the concerns of companies listed in this market. Listed companies are considered representative for the promotion of CSR considering the size of the companies; their existence on the market; and other considerations, such as "social, political and legal dimensions exert important pressure on firms improving the transparency of corporate behavior in particular on CSR disclosure" (Coluccia et al. 2018).

Similar indices are launched by Warsaw Stock Exchange from Poland (RESPECT index). Currently, BSE lists 83 companies from different fields of activity, which are structured on three segments-international, premium, and standard categories, and listed companies with domestic, mixed, or foreign capital. The stock market trend is followed by the BET index family launched by BSE and the ROTX index launched by BSE in collaboration with the Vienna Stock Exchange.

BET is the first index launched by BSE in 1997), i.e., the reference index of the local capital market. Initially, the index consisted of 10 companies, now, it has 17 components. BET reflects the evolution of the most traded companies on the regulated market of BSE (called generic blue chips), except for the five financial investment companies (FICs). This index is a price index weighted with the free float capitalization, with the maximum share of a company being $20 \%$.

The main selection criterion of the companies in the index is liquidity, but starting with 2015, BSE uses additional criteria regarding the transparency of issuers and the quality of their reporting and communication with investors. In this way, BSE is in line with the existing global trend regarding the increase in the transparency of listed companies and the improvement in the relationship with different categories of stakeholders, including investors. Portfolio investors have become increasingly responsible, and investment criteria are no longer based on profitability and risk but also on ESG aspects. Therefore, the process of reshaping the behavior of stock market investors and changing the paradigm regarding their role in the economy is also felt at BSE. So, the sample of companies uses the BET index because the companies in the basket of this index meet the criteria of liquidity and transparency, which act as the basis for the construction of this index.

To evaluate the information from companies' websites, the following thresholds were used:

- Short mention - the company has a page where it informs the stakeholders that it has CSR activity on different domains;

- Mention with examples-the company has a page where it informs the visitors that it has CSR activity and a list of CSR actions,

- Simple page with links to CSR reports-the company has a page with a short presentation of CSR activity, or not, and a list of links to CSR reports available on-line;

- Advance page with links to CSR reports and events-the company has multiple pages with a complex presentation of CSR activity, a list of CSR actions with/without links, and a list of links to CSR reports available on-line;

- Presentation classified by CSR domain-the company has multiple pages with a complex presentation of CSR activity on each domain, lists of CSR actions on each domain with links, and a list of links to CSR reports available online.

In Table 3, the results of CSR information from the companies' websites are presented. 
Table 3. Analysis of CSR information presented on companies' websites.

\begin{tabular}{|c|c|c|c|c|c|c|}
\hline \multirow{3}{*}{$\begin{array}{l}\text { Company } \\
\text { (Link) }\end{array}$} & \multicolumn{6}{|c|}{ Website } \\
\hline & $\begin{array}{l}\text { Year of Last } \\
\text { Report/ } \\
\text { Activity/ }\end{array}$ & $\begin{array}{l}\text { Short } \\
\text { Mention }\end{array}$ & $\begin{array}{l}\text { Mention } \\
\text { with } \\
\text { Examples }\end{array}$ & $\begin{array}{l}\text { Simple Page } \\
\text { with Links to } \\
\text { CSR Reports }\end{array}$ & $\begin{array}{l}\text { Advanced } \\
\text { Page with } \\
\text { Links to CSR } \\
\text { Reports and } \\
\text { Events }\end{array}$ & $\begin{array}{l}\text { Presentation } \\
\text { Classified by } \\
\text { CSR Domain }\end{array}$ \\
\hline & & Tier 3 & \multicolumn{2}{|c|}{ Tier 2} & \multicolumn{2}{|c|}{ Tier 1} \\
\hline $\begin{array}{l}\text { BANCA TRANSILVANIA S.A. } \\
\text { https: } \\
\text { / / www.bancatransilvania.ro/ }\end{array}$ & 2021 & & & & & $x$ \\
\hline $\begin{array}{l}\text { OMV PETROM S.A. } \\
\text { https://www.omvpetrom.com/ } \\
\text { ro/sustenabilitate/rapoarte-de- } \\
\text { sustenabilitate/premii-si- } \\
\text { recunoastere }\end{array}$ & 2020 & & & & & $\mathrm{x}$ \\
\hline $\begin{array}{l}\text { BRD_GROUPE SOCIETE } \\
\text { GENERALE S.A. } \\
\text { https:/ / www.brd.ro/despre-brd/ } \\
\text { responsabilitate/societatea-civila }\end{array}$ & 2020 & & $x$ & & & \\
\hline $\begin{array}{l}\text { S.N.G.N. ROMGAZ S.A. } \\
\text { https: } \\
\text { / / www.romgaz.ro/ro/content/ } \\
\text { responsabilitate-sociala-0 }\end{array}$ & 2020 & & & & & $x$ \\
\hline $\begin{array}{l}\text { SOCIETATEA ENERGETICA } \\
\text { ELECTRICA S.A. } \\
\text { https:/ / www.electrica.ro/csr/ }\end{array}$ & 2018 & & & & $x$ & \\
\hline $\begin{array}{c}\text { S.N.T.G.N. TRANSGAZ S.A. } \\
\text { https:// www.transgaz.ro/ro/ } \\
\text { responsabilitate-sociala/politica- } \\
\text { csr }\end{array}$ & 2020 & & $x$ & & & \\
\hline $\begin{array}{l}\text { S.N. NUCLEARELECTRICA S.A } \\
\text { https: } \\
\text { / / www.nuclearelectrica.ro/csr / }\end{array}$ & 2019 & & & $x$ & & \\
\hline $\begin{array}{c}\text { MEDLIFE S.A. } \\
\text { https://www.medlife.ro/csr }\end{array}$ & 2020 & & & & & $x$ \\
\hline $\begin{array}{c}\text { ALRO S.A. } \\
\text { http:/ / www.alro.ro/raspundere- } \\
\text { sociala }\end{array}$ & 2019 & & & $x$ & & \\
\hline $\begin{array}{l}\text { TERAPLAST SA } \\
\text { https://impreuna-cladim- } \\
\text { romania.teraplast.ro/ }\end{array}$ & 2019 & & & & & $x$ \\
\hline $\begin{array}{c}\text { CONPET SA } \\
\text { https:/ / www.conpet.ro/politici/ } \\
\text { responsabilitate-sociala/ }\end{array}$ & - & $x$ & & & & \\
\hline $\begin{array}{c}\text { BURSA DE VALORI BUCURESTI } \\
\text { SA } \\
\text { https: } \\
\text { / / www.bvb.ro/AboutUs/CSR }\end{array}$ & 2020 & & $\mathrm{x}$ & & & \\
\hline $\begin{array}{l}\text { SPHERA FRANCHISE GROUP } \\
\text { https://www.spheragroup.com/ }\end{array}$ & 2020 & & & & & $x$ \\
\hline
\end{tabular}


The companies have a different involvement, despite the fact that they are brand issuers of the Romanian capital market. The type of capital (local/foreign) or the field of activity does not influence the social behavior in the case of these companies.

\section{Index Calculation Formula}

The composition of the index is orientated towards promoting companies that have good CSR practices. This can be achieved by increasing the weight of the CSR activity in creating the index.

First, criteria proposed for inclusion of companies in the CSR index based on the previous evaluation are presented. This study proposes a three-tier scale for index calculation.

- $\quad$ Tier 1 is composed of companies with the highest activity and visibility of their CSR projects which can be achieved by releasing an annual report on CSR activity submitting it to a Reporting Agency and a complex website presentation and promotion of its CSR activity on companies' website. (1)

- $\quad$ Tier 2 is composed of companies that publish an annual report where CSR practices are presented or a complex website presentation of its CSR activity. (0.8)

- Tier 3 is composed of companies that present a short declaration of their participation in CSR activities or a short list of activities without many details. (0.4)

The second criterion is the timespan from the last CSR activity documented. In this case, scores will be used for the following situations:

- $\quad$ Less than 1 year (1);

- $\quad$ Between 1 and 2 years (0.8);

- $\quad$ Between 2 and 5 years (0.6);

- $\quad$ Older than 5 years $(0.2)$.

The criteria presented above will be used to adjust the market capitalization of each company and calculate the index.

The index will be calculated using the following formula:

$$
\operatorname{CSR}_{t}=\operatorname{CSR}_{t-1} \times \frac{\sum_{i=0}^{n} p_{i, t} \times q_{i, t} \times R_{i} \times \operatorname{CSR}_{i, t} \times T_{i, t}}{\sum_{i=0}^{n} p_{i, t-1} \times q_{i, t} \times R_{i} \times C S R_{i, t} \times T_{i, t}}
$$

where

$C S R_{t}$ - the value of the CSR index at current time, $t$.

$C S R_{t-1}-$ the value of the CSR index at the previous time, $t-1$.

$p_{i, t}$-companies $i$ stock price for current time, $t$.

$R_{i}$-representation factor at a maximum $20 \%$ weight for each component of the index, corresponding to companies' stock, which is calculated to three decimal places and belongs to the range $(0,1]$.

$p_{i, t-1}$-companies $i$ stock price for previous closing time, $t-1$.

$q_{i, t}$ - the number of shares at current time, $t$.

$C S R_{i, t}$ - CSR factor for company $i$.

$T_{i, t}$ - the time since the last CSR activity factor of company $i$.

This formula is chosen because it is similar to the one used to determine the BET index from the BSE (see Table 4).

The starting value of the index is expected to reach 1000 points.

After the index launch, several events and changes may affect its structure, such as splitting/consolidation, granting free shares, and granting the right to subscribe for new shares at a lower price than the market price. Other events may influence the structure of the index, such as admitting new companies in the index or excluding old ones. 
The price evolution must also be taken in consideration as its evolution could increase the weight of a company, resulting in a change in the representation factor. To consider these events, the variables of the index will be reviewed every trimester by an Index Commission. Usually, these reviews take place within 5 days before the futures contract's maturity from the quarterly cycle March-June-September-December; therefore, the change will come in force in the first day of trading for new contracts.

Table 4. Example of initial values for the CSR index.

\begin{tabular}{|c|c|c|c|c|c|c|}
\hline Company & $T_{i}$ & $C S R_{i}$ & $q_{i}$ & $p_{i}^{*}$ & $R_{i}$ & Weight \\
\hline $\begin{array}{c}\text { BANCA } \\
\text { TRANSILVANIA S.A. }\end{array}$ & 1 & 1 & $5,737,699,709$ & 2.6800 & 0.751 & 0.199921 \\
\hline $\begin{array}{l}\text { OMV PETROM S.A. } \\
\text { BRD—GROUPE }\end{array}$ & 1 & 1 & $56,644,108,335$ & 0.4010 & 0.508 & 0.19976 \\
\hline $\begin{array}{l}\text { SOCIETE GENERALE } \\
\text { S.A. }\end{array}$ & 1 & 0.8 & $696,901,518$ & 16.4000 & 1 & 0.158289 \\
\hline $\begin{array}{c}\text { S.N.G.N. ROMGAZ } \\
\text { S.A. } \\
\text { SOCIETATEA }\end{array}$ & 1 & 1 & $385,422,400$ & 30.2000 & 0.992 & 0.199895 \\
\hline $\begin{array}{c}\text { ENERGETICA } \\
\text { ELECTRICA S.A. }\end{array}$ & 0.6 & 1 & $346,443,597$ & 12.4000 & 1 & 0.044622 \\
\hline $\begin{array}{l}\text { S.N.T.G.N. TRANSGAZ } \\
\text { S.A. } \\
\text { S.N. NUCLEARELEC- }\end{array}$ & 1 & 0.8 & $11,773,844$ & 284.0000 & 1 & 0.04631 \\
\hline $\begin{array}{c}\text { TRICA } \\
\text { S.A }\end{array}$ & 0.6 & 0.8 & $301,643,894$ & 27.2000 & 1 & 0.068179 \\
\hline MEDLIFE S.A. & 1 & 1 & $132,870,492$ & 15.5000 & 1 & 0.035654 \\
\hline ALRO S.A. & 0.6 & 0.8 & $713,779,135$ & 2.6600 & 1 & 0.015777 \\
\hline TERAPLAST SA & 0.6 & 1 & $1,743,200,478$ & 0.8310 & 1 & 0.015047 \\
\hline CONPET SA & 0.2 & 0.4 & $8,657,528$ & 85.0000 & 1 & 0.001019 \\
\hline $\begin{array}{c}\text { BURSA DE VALORI } \\
\text { BUCURESTI SA }\end{array}$ & 1 & 0.8 & $8,049,246$ & 25.1000 & 1 & 0.002798 \\
\hline $\begin{array}{c}\text { SPHERA FRANCHISE } \\
\text { GROUP }\end{array}$ & 1 & 1 & $38,799,340$ & 18.9500 & 1 & 0.012729 \\
\hline
\end{tabular}

\section{Discussion, Conclusions, and Implications}

The paper offers several insights to managers and scholars about the role played by CSR indices. The paper, in fact, is the first to study the need to develop a proper CSR communication index for the companies listed in BSE.

The index can be seen by companies that will further develop it, text its validity, and employ it as a tool able to reassure the investors who will decide to spend their money to buy shares and stocks of organizations ranched in the BSE. A higher score will assure more confidence among investors in approaching a particular company, assuming that their financial, social, and environmental expectations will be totally fulfilled. In addition, the index can be used by brokers and other financial agencies to select the companies that will be presented to their customers.

In fact, as these players have to give advice to many potential investors who are interested in choosing suitable organizations in light of profit and requirements of the entire society, they must acknowledge their clients that pay much attention to CSR communication. Having said that, it is likely that it will be more appealing to companies to communicate systematically with different types of stakeholders, including investors, thanks to several communication channels. Thus, the index, corresponding with the new European Sustainable Equity (ESG) rating, is set to assess how the companies decide to build their resilient strategy to answer to long-term, environmental, social, and governance risks.

Nevertheless, there are some limitations for the tool. 
In fact, the level of complexity of the index is low because the data available from the BSE listed companies regarding CSR communication aspects are not standardized and every company has its own framework for CSR reporting. As a result, the use of more complex variables is not possible. If the BSE promotes the creation of a CSR index and/or a sustainability index and requests a standardized report, the companies will be more incentivized to disclose specific information to access the index composition.

This is a proposal for an index which is easy to construct based on existing data for the listed companies at BSE. After the index creation, if the interest of the companies and investors is high, it can begin a path of transformation through developing more complex ways to evaluate the CSR activity, by allowing the companies to make necessary changes and then introducing the new standards for index accession. This would allow companies that decide to be ranked in the index composition to take the needed actions to maintain and strengthen their CSR communication. The present study can be further developed by proposing new variables that could be used to better evaluate the CSR activities of companies.

The secondary capital market can play, up to a certain level, a favorable role in terms of the manifestation of social responsibility of companies and investors. When the instruments of the secondary capital market acquire par excellence and a speculative character, the question arises whether they still represent the ingredients of a well-functioning capital market or, on the contrary, disturbing or even parasitic elements. These are certain derivatives which are created to fuel the process of financial innovation and generate profits for certain investors. Some of them are toxic in the sense that they were not created to meet real needs from the economy but only to encourage the intensification of speculative processes. In fact, the effects of the crises are borne by the entire population, in which the strongest, in the negative sense, relates to the impact on people with low incomes.

This is why the theory of sustainable development has increasingly incorporated the so-called vector of business ethics, which, unfortunately, for a large part of capital market actors, refers to: (i) a utopian problem that is incompatible with the criteria of efficiency and profitability, declaring the cynicism of pursuing profit at any cost, regardless of the negative externalities it creates; and (ii) an issue with which companies agree to consider, but which is subsequently much less considered or even completely neglected. The recirculation of so-called securities, which have in fact turned into electronic documents, so far removed from reality but seductive in terms of potential gains, is a blinding factor for decision-makers due to the attractiveness of expectations relating to earnings. Even if there are a series of procedures, prudential rules, and risk management strategies, they have rather theoretical and methodological significance. The observance of these, sooner or later, becomes a matter of generating and using apparently legal means of non-compliance, as double accounting or fraud of internal control systems that generated major financial scandals for large transnational corporations or banks.

Author Contributions: Conceptualization, M.C.P., M.C.V.; methodology, M.C.P., M.C.V.; software, M.C.P., M.C.V.; validation, M.C.P., M.C.V., E.H., A.S., and M.P.; formal analysis, M.C.P., M.C.V.; investigation, M.C.P., M.C.V., E.H., A.S., and M.P.; resources, M.C.P., M.C.V.; data curation, M.C.P., M.C.V.; writing—original draft preparation, M.C.P., M.C.V.; writing—review and editing, M.C.P., M.C.V., E.H., A.S., and M.P.; visualization, M.C.P., M.C.V., E.H., A.S., and M.P.; supervision, M.C.P., M.C.V.; project administration, M.C.P., M.C.V. All authors have read and agreed to the published version of the manuscript.

Funding: This research received no external funding.

Institutional Review Board Statement: Not applicable.

Informed Consent Statement: Not applicable.

Data Availability Statement: Not applicable.

Conflicts of Interest: The authors declare no conflict of interest. 


\section{References}

Adam, Avshalom Madhala, and Tal Shavit. 2008. How can a ratings-based method for assessing corporate social responsibility (CSR) provide an incentive to firms excluded from socially responsible investment indices to invest in CSR? Journal of Business Ethics 82 : 899-905. [CrossRef]

Amor-Esteban, Víctor, Ma-Purificación Galindo-Villardón, and Isabel-María García-Sánchez. 2018. Industry mimetic isomorphism and sustainable development based on the X-STATIS and HJ-biplot methods. Environmental Science and Pollution Research 25 : 26192-208. [CrossRef] [PubMed]

Amor-Esteban, Víctor, María Purificación Galindo-Villardón, and Isabel-María García-Sánchez. 2020. Bias in composite indexes of CSR practice: An analysis of CUR matrix decomposition. Corporate Social Responsibility and Environmental Management 27: 1914-36. [CrossRef]

Andrei, Jean Vasile, Mirela Panait, and Cătălin Voica. 2018. Challenges and approaches for the corporate social responsibility and human resource management in the financial sector. Economics, Management and Financial Markets 13: 415-31.

Anghelache, Gabriela. 2007. The capital market in the context of the integration within the European Union. Theoretical and Applied Economics 9: 21-28.

Anghelache, Gabriela, and Mirela Panait. 2016. Characteristics of the Romanian capital market. Romanian Statistical Review Supplement 64: 79-89.

Apostu, Simona-Andreea, Manuela Tureatca, Valentina Vasile, and Valentin Sava. 2019. Relations between Public Spending and Sustainable Development, in the Romanian Economy. A Century of Transformation (1918-2018). Berlin: Peter Lang International Academic Publishing Group, vol. 1, pp. 447-57.

Arribas, Iván, María Dolores Espinós-Vañó, Fernando García, and Paula Beatriz Morales-Bañuelos. 2019. The inclusion of socially irresponsible companies in sustainable stock indices. Sustainability 11: 2047. [CrossRef]

Barna, Flavia, and Petru-Ovidiu Mura. 2010. Capital market development and economic growth: The case of Romania. Annals of the University of Petrosani, Economics 10: 31-42.

Batista, Alamo Alexandre da Silva, and Antonio Carlos de Francisco. 2018. Organizational sustainability practices: A study of the firms listed by the corporate sustainability index. Sustainability 10: 226. [CrossRef]

Beckert, Jens. 2010. Institutional isomorphism revisited: Convergence and divergence in institutional change. Sociological Theory 28: 150-66. [CrossRef]

Brasoveanu, Laura Obreja, Victor Dragota, Delia Catarama, and Andreea Semenescu. 2008. Correlations between capital market development and economic growth: The case of Romania. Journal of Applied Quantitative Methods 3: 64-75.

Brezoi, Alina Gabriela. 2018. Ethics and corporate social responsibility in the current geopolitical context. Economic Insights-Trends and Challenges 7: 45-52.

Coluccia, Daniela, Stefano Fontana, and Silvia Solimene. 2018. Does institutional context affect CSR disclosure? A study on Eurostoxx 50. Sustainability 10: 2823. [CrossRef]

Corsini, Lucia, Valeria Dammicco, and James Moultrie. 2021. Frugal innovation in a crisis: The digital fabrication maker response to COVID-19. RED Management 51: 195-210.

Cozorici, Angela-Nicoleta, and Gabriela Prelipcean. 2015. Aspects Regarding Stocks and Bonds Portfolios on Romanian Capital Market. Procedia Economics and Finance 32: 1012-19. [CrossRef]

Daszyńska-Żygadło, Karolina. 2019. Impact of CSR on Operating Financial Results: The Case of Companies from RESPECT Index. In Corporate Social Responsibility in Poland. Cham: Springer, pp. 59-72.

DiMaggio, Paul J., and Walter W. Powell. 1983. The iron cage revisited: Institutional isomorphism and collective rationality in organizational fields. American Sociological Review 48: 147-60. [CrossRef]

Dobrowolski, Zbysław, and Łukasz Sułkowski. 2020. Implementing a sustainable model for anti-money laundering in the United Nations development goals. Sustainability 12: 244. [CrossRef]

Drăgoi, Mihaela Cristina, Maria-Floriana Popescu, Jean Vasile Andrei, and Mihai Mieilă. 2018. Developments of the Circular Economy in Romania under the New Sustainability Paradigm. Economic Computation E Economic Cybernetics Studies E Research 52: 2.

Dragotã, Victor. 2006. Minority shareholders' protection in Romanian capital markets: Evidence on dividends. Euro-Mediterranean Economics and Finance Review 1: 76-89.

Dragota, Victor, Andreea Maria Stoian, Daniel Traian Pele, Eugen Mitrica, and Malik Kamel Bensafta. 2009. The development of the Romanian capital market: Evidences on information efficiency. Romanian Journal of Economic Forecasting 10: 147-60.

Ene, Corina, and Mirela Panait. 2017. The financial education-Part of corporate social responsibility for employees and customers. Revista Romana de Economie 44: 145-54.

EU Parliament's. 2020. Corporate Social Responsibility (CSR) and Its Implementation into EU Company Law. Available online: https: / / www.europarl.europa.eu/RegData/etudes/STUD/2020/658541/IPOL_STU(2020)658541_EN.pdf (accessed on 15 February 2022).

Frone, Simona, Victor Platon, and Andreea Constantinescu. 2020. Links and synergies of sustainable development goals. Annals of Constantin Brancusi University of Targu-Jiu, Economy Series 20: 5.

Gigauri, Iza. 2021. Corporate Social Responsibility and COVID-19 Pandemic Crisis: Evidence from Georgia. International Journal of Sustainable Entrepreneurship and Corporate Social Responsibility (IJSECSR) 6: 30-47. [CrossRef] 
Gjølberg, Maria. 2009. Measuring the immeasurable? Constructing an index of CSR practices and CSR performance in 20 countries. Scandinavian Journal of Management 25: 10-22. [CrossRef]

Gurtu, Amulya, ed. 2020. Recent Advancements in Sustainable Entrepreneurship and Corporate Social Responsibility. Hershey: IGI Global.

Hysa, Eglantina. 2014. Defining a 21st Century Education: Case Study of Development and Growth Course. Mediterranean Journal of Social Sciences 5: 41. [CrossRef]

Hysa, Eglantina, and Egla Mansi. 2020. Integrating teaching and learning in graduate studies: Economic development course. Technology Transfer: Innovative Solutions in Social Sciences and Humanities 3: 61-64. [CrossRef]

Khan, Syed Abdul Rehman, Zhang Yu, Hêriş Golpîra, and Arshian Sharif. 2019. The nexus between corporate social responsibility and corporate performance: An empirical evidence. LogForum 15: 2. [CrossRef]

Khan, Syed Abdul Rehman, Zhang Yu, Mirela Panait, Laeeq Razzak Janjua, and Adeel Shah, eds. 2021. Global Corporate Social Responsibility Initiatives for Reluctant Businesses. Hershey: IGI Global.

Lee, Myeongju, and Hyunok Kim. 2017. Exploring the organizational culture's moderating role of effects of Corporate Social Responsibility (CSR) on firm performance: Focused on corporate contributions in Korea. Sustainability 9: 1883. [CrossRef]

Lemke, Claudia, and Karola Bastini. 2020. Embracing multiple perspectives of sustainable development in a composite measure: The Multilevel Sustainable Development Index. Journal of Cleaner Production 246: 118884. [CrossRef]

Manea, Daniela Ioana, Ţiţan Emilia, Mihai Mihaela, Apostu Simona-Andreea, and Vasile Valentina. 2020. Good practices on air quality, pollution and health impact at EU level. Amfiteatru Economic 22: 256-74.

Manta, Otilia, Eglantina Hysa, and Alba Kruja. 2021. Finances and National Economy: Frugal Economy as a Forced Approach of the COVID Pandemic. Sustainability 13: 6470. [CrossRef]

Masud, Md, Abdul Kaium, Md Rashid, Harun Ur, Tehmina Khan, Seong Mi Bae, and Jong Dae Kim. 2019. Organizational strategy and corporate social responsibility: The mediating effect of triple bottom line. International Journal of Environmental Research and Public Health 16: 4559. [CrossRef] [PubMed]

Matei, Mirela. 2013. Responsabilitatea Socială a Corporaţiilor şi Instituţiilor şi Dezvoltarea Durabilă a României. Bucharest: Expert Publishing House.

Matei, Mirela, Adrian Stancu, George Enescu, and Corina Geambaşu. 2008. Burse de mărfuri şi valori. Ploieşti: Editura Universităţi din Ploieşti.

Morina, Fatbardha, Eglantina Hysa, Uğur Ergün, Mirela Panait, and Marian C. Voica. 2020. The effect of exchange rate volatility on economic growth: Case of the CEE countries. Journal of Risk and Financial Management 13: 177. [CrossRef]

Mynhardt, Henry, Inna Makarenko, and Alex Plastun. 2017. Market efficiency of traditional stock market indices and social responsible indices: The role of sustainability reporting. Investment Management and Financial Innovations 14: 94-106. [CrossRef]

Najm-Ul-Sehar, Bilal, and Sumaira Tufail. 2013. Determinants of voluntary disclosure in annual report: A case study of Pakistan. Management and Administrative Sciences Review 2: 181-95.

Nakai, Miwa, Keiko Yamaguchi, and Kenji Takeuchi. 2013. Sustainability membership and stock price: An empirical study using the Morningstar-SRI Index. Applied Financial Economics 23: 71-77. [CrossRef]

Naseem, Muhammad Akram, Muhammad Ishfaq Ahmad, Ramiz Ur Rehman, Muhammad Asif Khan, and Rizwan Ali. 2019. The Trend and Development of CSR Disclosure in Chinese Listed Firms. Agathos 10: 267-79.

Palazzo, Maria. 2019. Linking Cultural Dimensions and CSR Communication: Emerging Research and Opportunities (the Manuscript). Hershey: IGI Global.

Palazzo, Maria, Agostino Vollero, Pantea Foroudi, and Alfonso Siano. 2019. Evaluating constitutive dimensions of CSR ecommunication: A comparison between 'Business-To-Business' and 'Close-To-Market' companies. Journal of Business-to-Business Marketing 26: 341-55. [CrossRef]

Palazzo, Maria, Agostino Vollero, and Alfonso Siano. 2020a. From strategic corporate social responsibility to value creation: An analysis of corporate website communication in the banking sector. International Journal of Bank Marketing 38: 1529-52. [CrossRef]

Palazzo, Maria, Linda Deigh, Pantea Foroudi, and Alfonso Siano. 2020b. How to boost place branding leveraging on community relations: An exploration of the banking sector in Ghana. Qualitative Market Research: An International Journal 23: 933-60. [CrossRef]

Panait, Mirela, Razvan Ionescu, Irina Gabriela Radulescu, and Husam Rjoub. 2021. The Corporate Social Responsibility on Capital Market: Myth or Reality? In Financial Management and Risk Analysis Strategies for Business Sustainability. Hershey: IGI Global, pp. 219-53.

Peršić, Milena, Sandra Janković, and Dubravka Krivačić. 2017. Sustainability accounting: Upgrading corporate social responsibility. In The Dynamics of Corporate Social Responsibility. Cham: Springer, pp. 285-303.

Raimi, Lukman, Innocent Akhuemonkhan, and Olakunle Dare Ogunjirin. 2015. Corporate Social Responsibility and Entrepreneurship (CSRE): Antidotes to poverty, insecurity and underdevelopment in Nigeria. Social Responsibility Journal 11: 56-81. [CrossRef]

Searcy, Cory, and Doaa Elkhawas. 2012. Corporate sustainability ratings: An investigation into how corporations use the Dow Jones Sustainability Index. Journal of Cleaner Production 35: 79-92. [CrossRef]

Siano, Alfonso, Lukman Raimi, Maria Palazzo, and Mirela Clementina Panait. 2020. Mobile Banking: An Innovative Solution for Increasing Financial Inclusion in Sub-Saharan African Countries: Evidence from Nigeria. Sustainability 12: 10130. [CrossRef]

Skouloudis, Antonis, David Isaac, and Kostis Evaggelinos. 2016. Revisiting the national corporate social responsibility index. International Journal of Sustainable Development \& World Ecology 23: 61-70. 
Sułkowski, Łukasz, and Zbysław Dobrowolski. 2021. The role of supreme audit institutions in energy accountability in EU countries. Energy Policy 156: 112413. [CrossRef]

Sun, Mei, Katsuya Nagata, and Hiroshi Onoda. 2011. The investigation of the current status of socially responsible investment indices. Journal of Economics and International Finance 3: 676-84.

Tiron-Tudor, Adriana, and Cristina Silvia Nistor. 2019. Încadrarea Raportării Nefinanciare Într-Un Cadru Coercitiv Menit Să Întărească Responsabilitatea Socială: Cazul Companiilor Listate Din Romania. Revista Amfiteatru Economic 435: 590-606.

Ur Rehman, Ramiz, Muhammad Zain ul Abidin, Rizwan Ali, Safwan Mohd Nor, Muhammad Akram Naseem, Mudassar Hasan, and Muhammad Ishfaq Ahmad. 2021. The Integration of Conventional Equity Indices with Environmental, Social, and Governance Indices: Evidence from Emerging Economies. Sustainability 13: 676. [CrossRef]

Vasile, Valentina, Panait Mirela, and Apostu Simona-Andreea. 2021. Financial inclusion paradigm shift in the postpandemic period. digital-divide and gender gap. International Journal of Environmental Research and Public Health 18: 10938. [CrossRef]

Venturelli, Andrea, Fabio Caputo, Rossella Leopizzi, Giovanni Mastroleo, and Chiara Mio. 2017. How can CSR identity be evaluated? A pilot study using a Fuzzy Expert System. Journal of Cleaner Production 141: 1000-10.

Vesci, Massimiliano, Rosangela Feola, Roberto Parente, and Navi Radjou. 2021. How to save the world during a pandemic event. A case study of frugal innovation. RED Management 51: 352-63.

Vollero, Agostino, Maria Palazzo, Alfonso Siano, and Domenico Sardanelli. 2018. Managing CSR communication: A study of legitimacy-seeking strategies adopted by service and product companies. The TQM Journal 30: 621-37. [CrossRef]

$\mathrm{Wu}$, Susie Ruqun, Changliang Shao, and Jiquan Chen. 2018. Approaches on the screening methods for materiality in sustainability reporting. Sustainability 10: 3233. [CrossRef]

Yang, Minghui, Paulo Bento, and Ahsan Akbar. 2019. Does CSR influence firm performance indicators? Evidence from Chinese pharmaceutical enterprises. Sustainability 11: 5656. [CrossRef]

Yu, Zhang, Syed Abdul Rehman Khan, and Yujuan Liu. 2020. Exploring the role of corporate social responsibility practices in Enterprises. Journal of Advanced Manufacturing Systems 19: 449-61. [CrossRef]

Zaman, Gheorghe, and Zizi Goschin. 2010. Multidisciplinarity, Interdisciplinarity and Transdisciplinarity: Theoretical Approaches and Implications for the Strategy of Post-Crisis Sustainable Development. Theoretical \& Applied Economics 17: 5-20.

Zaman, Gheorghe, Valentina Vasile, and Anca Cristea. 2012. Oustanding Aspects of Sustainable Development and Competitiveness Challenges for Entrepreneurship in Romania. Procedia Economics and Finance 3: 12-17. [CrossRef] 